\title{
THE INFLUENCE OF WORLD CPO PRICE ON REAL EXCHANGE RATE OF RUPIAH THROUGH THE CHANGES OF MONEY SUPPLY, INTEREST RATE AND INFLATION
}

\author{
Rizky Amelia Zahrah Lubis ${ }^{1}$, Dede Ruslan ${ }^{1}$, Andri Zainal $^{1}$ \\ ${ }^{1}$ Universitas Negeri Medan (Medan State University), Medan, Indonesia \\ *Corresponding Author: rizkyamelialubis92@gmail.com
}

\begin{abstract}
The aim of this research is to anaylse the influence of world CPO price on real exchange rate of Rupiah through the changes of money supply, interest rate, and inflation. This is a quantitative research employing eviews 6.0. This current research hasshown that the influence of world CPO price to real exchange rate of Rupiah through the changes of money supply, interest rate, and inflation in Indonesia between 2008(q1-q4) - 2015(q1-q4)) is significant and of positive value. Data analysis in this research wasemploying descriptive method, equipped with econometric data analysis with double linier regression analysis model applied by using regression. The simultanous equivalence was done by Two-Stage Square / 2 SLS) model.
\end{abstract}

KeyWords: Real Exchange Rate of Rupiah, World CPO Price, Supply of Money, Interest Rate, Inflation

\section{INTRODUCTION}

According to a research conducted by Istiqomah (2013), trading activity is a form of economic activity in a certain area or region and it is conducted between countries to fulfill the needs of a country and is commonly known as international trading. Therefore, interaction with outside world is inevitable for any country, including Indonesia. The essence of trading is the process of exchange. To simplify trading, the process requires comparison of currency values between the trading countries. In an exchange process, agreement on the exchange rate or the use of currency acceptable and agreed by all economy players is necessary.

Pratiwi and Santosa (2012) explain the importance of the roles of good exchange rate for developed and developing countries and urge the implementation of measures to maintain the exchange rate of a country in a stable and predictable fluctuation exchange condition and stable economy condition. Dornbusch (2008) asserts that a stable exchange rate shows that a country is in a relatively stable economy condition.

Pratiwi and Santosa (2012) claim that Indonesia has undergone several currency system changes. In April 1978, a fixed echange rate system was replaced by managed floating exchange rate system, which caused revenue reserve acquired from export could be traded freely and showed flexibility of Indonesian Rupiah (IDR) against American Dollar (USD). In August 1997, the government decided to replace managed floating exchange rate system with free floating exchange rate system. In this system, the exchange rate is determined by the market merchanism. This means that the role of commodity price in the international market will increase in the changes of a country's real exchange.

Aprina (2014) states that the important role of palm trees is its enormous contribution to the Indonesian economy through export.Palm products, namely Crude Palm Oil (CPO), is the main ingredient of one of the alternative energy sources which can substitute crude oil, which is biodiesel. This, of course, affects the world's demand for CPO.

TABLE 1. The World's Main Producers of CPO in 2008-2015 Volume (000/Tonnes)

\begin{tabular}{lcccccccc}
\hline Year & 2008 & 2009 & 2010 & 2011 & 2012 & 2013 & 2014 & 2015 \\
\hline Indonesia & 19,200 & 21,000 & 22,100 & 24,100 & 26,300 & 28,500 & 30,800 & 31,284 \\
Malaysia & 17,735 & 17,560 & 16,993 & 18,912 & 18,650 & 19,216 & 19,930 & 21,000
\end{tabular}




\begin{tabular}{lcccccccc} 
Thailand & 1,300 & 1,310 & 1,380 & 1,530 & 1,600 & 1,970 & 1,930 & 2,300 \\
Nigeria & 830 & 870 & 885 & 930 & 940 & 970 & 1,010 & 970 \\
Columbia & 778 & 802 & 753 & 941 & 970 & 1,040 & 1,120 & 1,175 \\
Ecuador & 418 & 448 & 380 & 495 & 550 & 495 & 515 & 560 \\
Other & 3,045 & 3,107 & 3,367 & 3,650 & 3,804 & 4,123 & 4,281 & 4,385 \\
\hline
\end{tabular}

Based on the table above, Indonesia is one of the biggest producers of CPO in the world with the growing number of production per year. Indonesia, followed by Malaysia, is one of the most preferrable producers of CPO and this consequently affects the exchange rate positively. The increase of production value also increases the development of the plantation and the palm oil industry in Indonesia in meeting with the demand of this growth. From the perspective of demand, Indonesia and Malaysia are the two countries with the biggest demand of CPO in the world. Up to 2015, Indonesia reached 31,284 million tonnes while Malaysia produced 21,000 million tones.

FIGURE 1. The Percentage of CPO Price Changes to the Real Exchange Rate in (2008-2015)

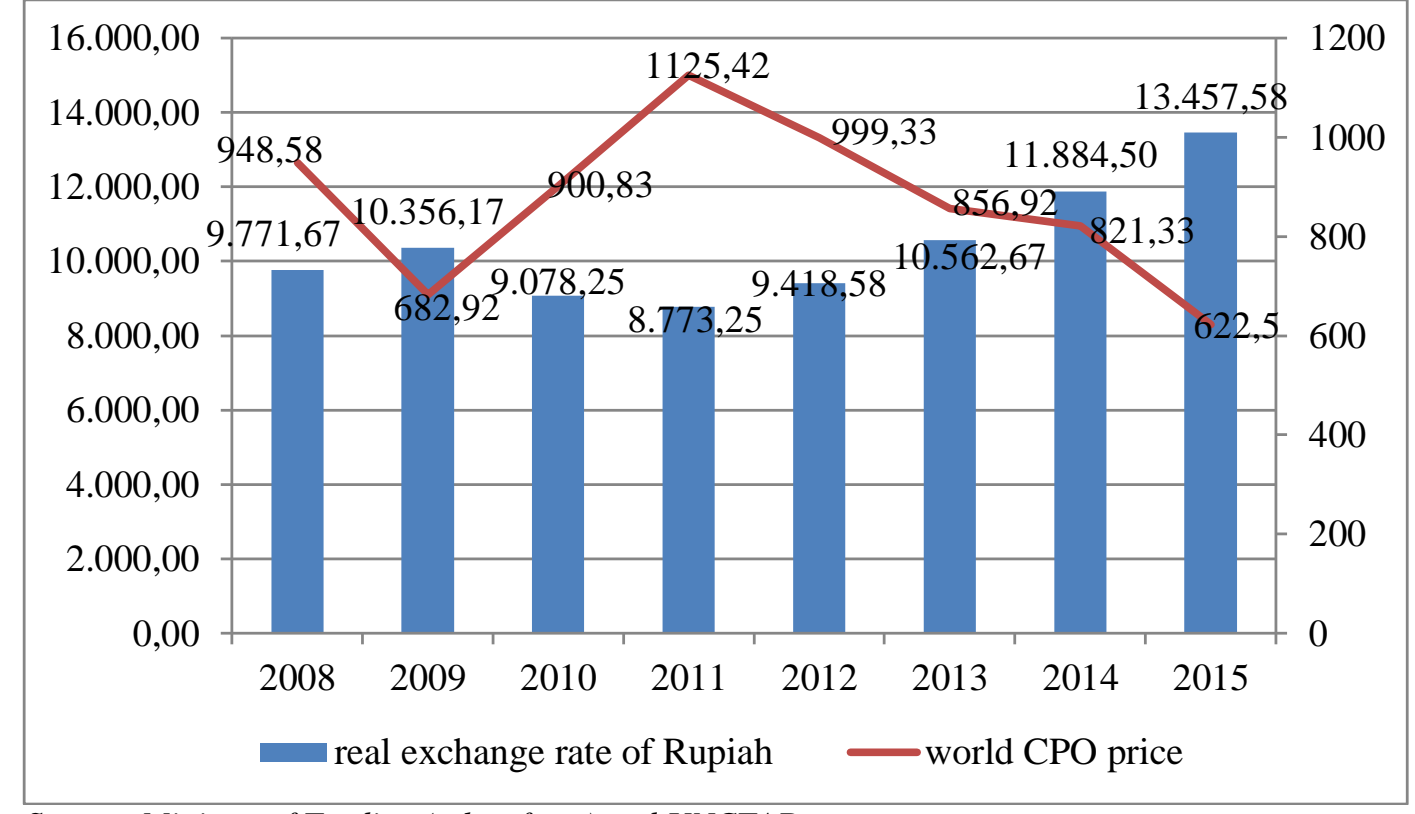

Source: Ministry of Trading (taken from) and UNCTAD.

From the figure above, it can be seen that CPO price is unstable because of the worsening of the trading policies, meaning that the value of export goods tends to decrease. The price of palm oil falls because the growth of world economy is slowly moving. The CPO price in the world can affect the changes in the exchange rate of Rupiah. The rise of world's CPO price can contribute positively to Indonesia's export of CPO. Chen and Rogoff (2003) state that the changes of export commodity price in general give positive influence to the real exchange rate. Wirdayanti (2017) suggest that CPO is a plantation product that becomes the main export commodity for Indonesia because of its high production level. Domestic and international CPO pricesfluctuate from time to time because its general primary product cost is agriculture cost and CPO is expected to be relatively difficult with high accuracy level.

Reflecting from the above explanation, this research explains whether there are influences contributed by the world's CPO price to the real exchange rate of Rupiah through changes of money supply, interest rate, and inflation in 2008(Q1-Q4) - 2015(Q1-Q4). This research analyses the influence of world's CPO price to the real exchange rate of Rupiah through the changes of money supply, interest rate, and inflation in 2008(Q1-Q4) - 2015(Q1-Q4). This research is expected to give general description about the influence of world's crude palm oil price to the real exchange rate through the changes in money supply, interest rate, and inflation. 


\section{LITERATURE REVIEW}

\subsection{Real Exchange Rate of Rupiah}

Huda and Widodo (2017) explain that if the exchange rate of Rupiah is depreciated against foreign currencies, the export value will increase while the import value will fall (if the offer for export and demand for import are relatively realistic). This is because in international market, domestic products become competitive. The increase of nett export value contributes to the rise of real agregate of demand and thus influences the rise of investment. Conversely, if the exchange rate of Rupiah suffers an appreciation, the export value will decrease, because domestic product value becomes relatively costly.

"Exchange rate of two countries is the price level which is agreed by the citizens of both countries to conduct trading". An increase in exchange rate is referred to as depreciation or the decrease of currency value of a country against a foreign currency. A decrease in exchange rate is called appreciation, or increase in the value of currency of a country, as asserted by Sukirno (1981).

Aprina (2014) suggests that real exchange rate of two countries is calculated from the nominal exchange rate and real exchange rate. If the real exchange rate is high, goods from abroad are relatively cheap and domestic goods become relatively more expensive. Mankiw (2007) states that the decisive factor of real exchange rate can be illustrated in graph 2.1 below.

\section{GRAPH 2.1. Factors Influencing Real Exchange Rate}

Real Exchange Rate, REER S-I

Equiblirium Exchange Rate

Nett Export, NX

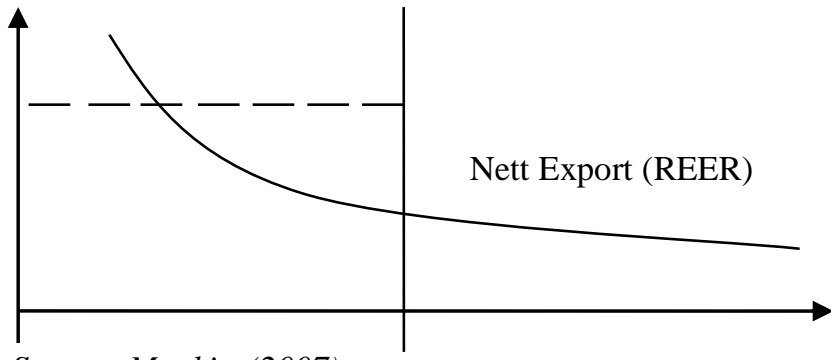

Source :Mankiw (2007)

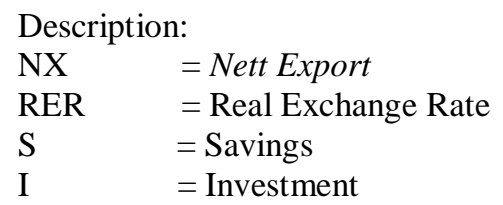

The graph above displays that the relation between nett export and real exchange rate is showing negative slope because the lower the real exchange rate the relatively cheaper the prices of domestic goods are. The line indicates the deviation between savings and investment (S-I) in vertical line because it is not affected by exchange rate. Exchange rate which is used in the graph above is the value of USD against other currencies; therefore, the direction is different. If the exchange rate experiences depreciation, which means the domestic value of the currency falls and that the value of foreign currency increases, this state will increase the volume of export and increase the import.

\subsection{Supply of Money}

Sukirno (1998) states that in the monetary theory, money supply means the same as the amount of money circulating. The amount of money circulating can be defined as the cartal money and exchange money. Widodo (1990) also states that this way the narrow definition of the amount of money circulating is defined as M1, which is the entirity of cartal money and exchange money held by the people and saved in general banks. The amount of money circulating (supply of money) M1 consists entirely of bills and coins and are saved in a form of exchange money. Nilawati (2000) suggests a broader definition about the amount of money circulating as M2 which is the combination of M1 and quasi-money.

When the supply of money is high, the interest rate decreases. By conducting tight money policy, the government is able to control the amount of money circulating. Conversely, when the supply of money is low, the interest rate rises. If the interest rate is high, people will automatically save their fund in the bank because they expect to gain profitable return. In this position, the demand of the people to have cash money becomes lower because they allocate the money in the form of bank portfolio (deposit and savings). As the supply of money falls, the excitement for shopping decreases. This is followed by the stagnancy of price of goods and public services, meaning that there 
is no inflation impulse. On the other hand, if the interest rate is low, people tend to no longer be interested in saving their money in the bank. According to the liquidity preference theory, the decrease of supply of money increases the interest rate, as explained by Prasetiantono (2000).

\subsection{Interest Rate}

Subagyo et al (2005) suggest that interest rate is the rate of loan cost or price paid for loan fund, presented in the form of percentage. Therefore, interest rate can also be defined as money acquired from loan given. Interest rate generally has two definitions based on the cases; for bank and for business person. For bank, interest rate is an income or profitfrom loan taken by a business person or a customer. For a business person, interest is considered as production cost or capital expense.

Khalwaty (2010) puts it that high interest rate encourages investors to invest their fund in the banks more than to invest in other production sectors or high risk sectors. Therefore, the inflation can be managed through interest rate policy. People who invest their fund in the bank, either in the form of savings, deposit, or current account will be subjected to high saving interest rate (in percentage). This interest rate is an incentive from the bank so that people are more motivated to invest in banks. The higher the saving interest rate, the more they will get the benefit. Conversely, the lower the interest rate for savings, the lower the motivation to save money in the bank will be because people will think that the benefit they will get from the interest rate in the future will be lower.

Ditria et al (2008) assert that interest rate is classified into fixed interest rate and floating interest rate. Fixed interest rate means that the interest rate will not change throughout the credit period; while floating interest rate means that the interest rate will change over time by following a certain exchange rate reference. Interest rate can change if either demand or supply of money does not reach balance. For instance, when the economy enters an expansion stage of a business cycle and increases the Real Gross Domestic Product (GDP), the financial transaction will rise, which causes the increase in the demand of money while at the same time supply remains the same. In this imbalance situation, interest rate will move in order to achieve balance between supply and demand of money. Interest rate which experiences increase and decrease affects the consumption expense of people. According to Sukirno (2004), the curve of demand against savings in different interest rates can be seen in graph 2.2 below.

\section{GRAPH 2.2. Determining Interest Rate}

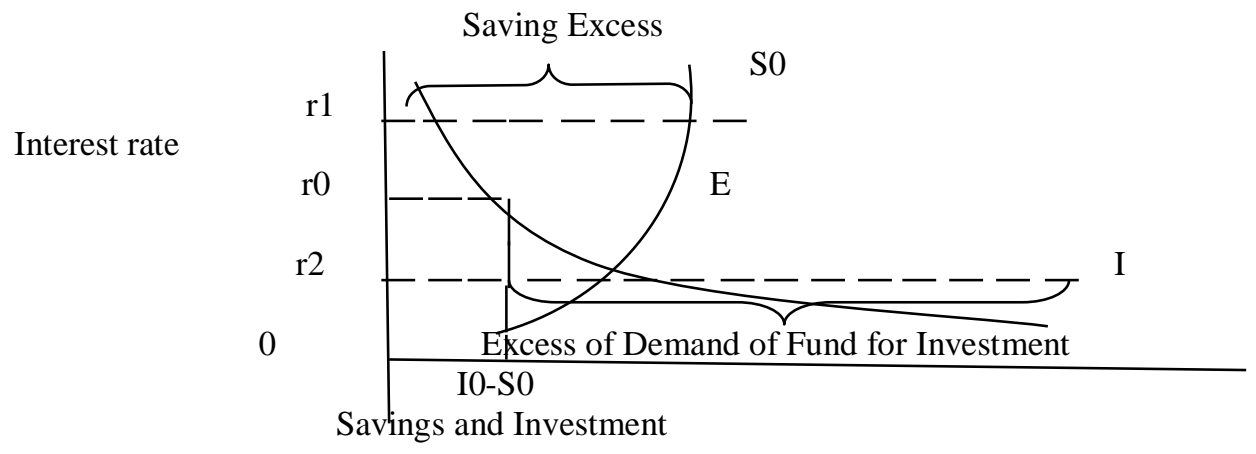

Source: Sukirno (2004)

Description:

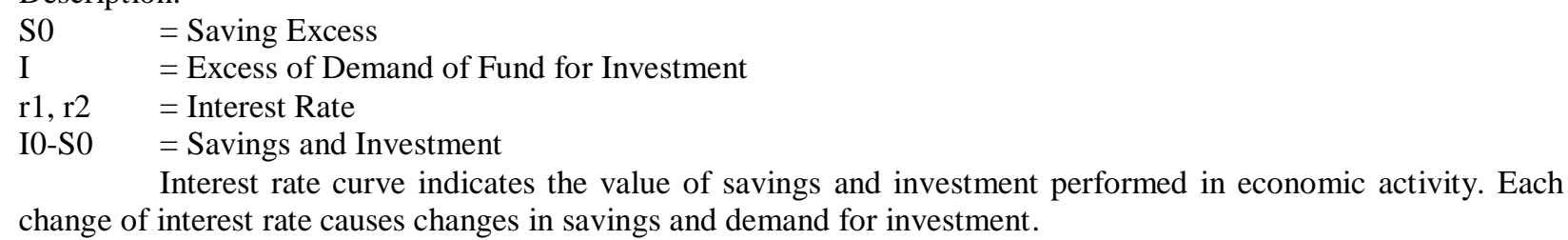

\subsection{Inflation}

Sitepu (2005) explains inflation as a situation where there is excess in demand against goods in economy, occuring continuously and thoroughly. Types of inflation can be classified into several categories, as asserted by Johan et al (2016), which are based on the nature and causes of occurence. Based on the nature of the inflation, there are mild inflation $(<10 \%$ per year), intermediate inflation (10-30\% in a year), severe inflation (30-100\% per year), and hyper inflation $(>100 \%)$. Based on the causes, there are:

Demand pull inflation which happens because of increase in the agregate demand, in which the economy is in the stage of no change of employment or if the production condition is in the stage where there is no employment 
possible. The increase of demand cannot push the increase in the output or production, but only able to push the increase of prices, which is referred as pure inflation. The increase of demand which exceeds the domestic gross product causes inflationary gap which causes inflation.

In Cost Push Inflation, the rate of offer is lower than that of the demand. Because there is an increase in the production cost, producer is forced to decrease the production to a certain amount. Theagregate offer constantly decreases due to the increase in the production cost. Inflation and unemployment can give positive and negative impacts. Positive relation can happen if the inflation calculated is inflation on prices of products in general, meaning that the rate of the inflation will trigger the increase of saving interest and loans.

Madura (2006) explains that the change in the inflation rate can affect the international trading activity. If inflation rate in a country rises, the demand of their currency will decrease because the export is also decreasing (caused by the price getting higher). Meanwhile, the consumers and companies in that country tend to increase the import.

\subsection{CPO Export}

Radifan (2014) claims that CPO is a product from Indonesian agriculture sector which is considered as the leading exporter of CPO in the world. However, the export of CPO starting from 2012 tends to decrease. Hardy (2015) suggests that theoretically export of a good is influenced by the supply and the demand. In theory of international trading, it is explained that the factors which influence the rate of export are supply and demand. Turnip (2016) states that international trading is a trading which reaches across countries' boundaries and includes export and import.

Chen and Rogoff (2003) suggest that there are relations between the exchange rate and export commodities. They assert that real exchange rate of Australia and New Zealand is influenced by the price of world's commodity. Wulansari et al., (2016) suggest that export is a transaction of products and services from Indonesia to other countries which causes payment by buyers from other countries. Export transaction allows money to come to Indonesia in a form of foreign currency. When exporters (sellers from Indonesia) receive payment from foreign country, they will exchange the foreign currency with Rupiah so that it can be used as capital for the purchase of raw materials and other operational expenses in order to make new products. When the exchange rate of Rupiah decreases, the amount of Rupiah gained by exporters increases compared to the previous exchange rate and vice versa. Based on framework below, the price of CPO contributes significantly to the changes of real exchange rate of Rupiah through the changes of money supply, interest rate, and inflation in 2008 (Q1-Q4) - 2015 (Q1-Q4).

FIGURE 2. RESEARCH FRAMEWORK

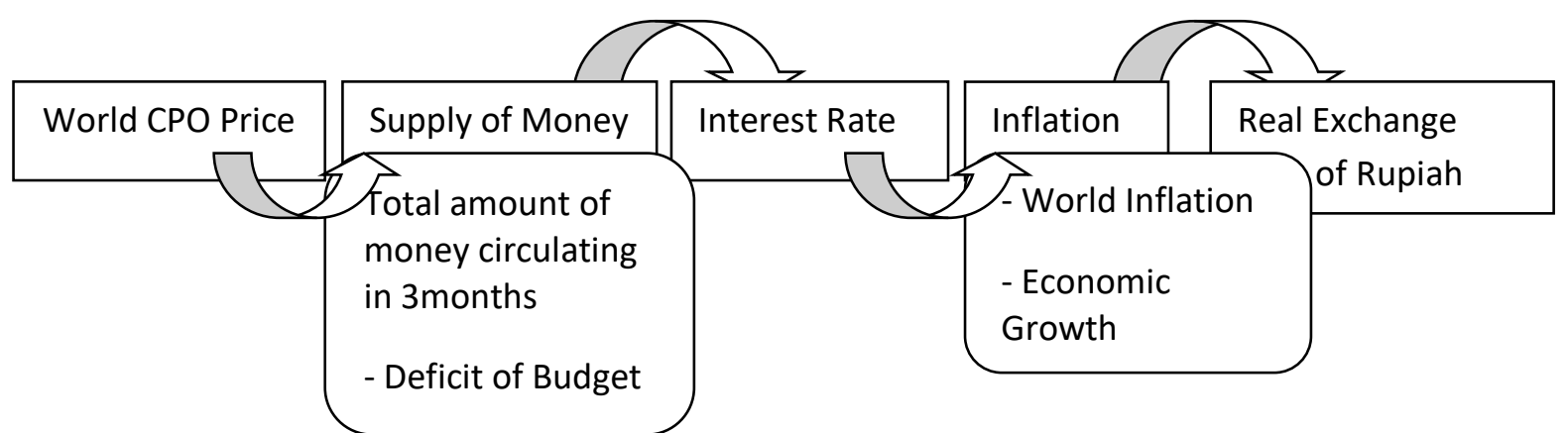

World's CPO price influences the increase of money supply such as deficit of budget. When the supply of money experiences appreciation, the interest rate is depreciated so that the inflation such as world inflation and economic growth affects the appreciation of real exchange rate of Rupiah.

\section{METHODOLOGY}

\subsection{The Identification of Simultanous Equation}

There are two types of simultanous model equation, structural equation and reduced form equation. Structural equation is the original equation which describes the behaviour relation between variables in the equation. While reduced form equation is an equation which is obtained from the structural equations which are already connected. By finishing the reduced form equation, we can calculate the coefficients of structural equation. Therefore, the estimation against structural equation will depend on the result of the estimation of reduced form equation. It needs model identification before choosing the method to estimate the parameter for each equation in the model. Gujarati (2012) suggests that to estimate the parameter, the model of simultanous equation must be identified first. Based on 
the identification test of simultanous equation above, it is shown that the equation is over identified; therefore, the research model used is Two Stage Least Square (TSLS).

\subsection{Data and Source}

This research uses secondary data acquired from information complied and publicized by certain institutions, such as Bank of Indonesia, The Central Bureau of Statistics, Ministry of Trading and UNCTAD (United Nations Conference On Trade and Development). The data collected are developed by Eviews 6.0.

\subsection{Sample}

The sample used in this current research is the influence of the world's CPO price to the changes of exchange rate of Rupiah through the changes of money supply, interest rate, and inflation in Indonesia. This research uses simultanous equation model to find over identified equation, between the influence of world CPO price to the changes of exchange rate of Rupiah through the changes of money supply, interest rate, and inflation. The model used in this research is modified from Edward (1986) and Aprina (2014).

Supply of Money Function

$\operatorname{Ln}\left(\mathrm{M}_{\mathrm{t}}\right)=\alpha_{0}+\alpha_{1} \operatorname{Ln}\left(\mathrm{M}_{\mathrm{t}-1}\right)+\alpha_{2} \operatorname{Ln}\left(\mathrm{DEH}_{\mathrm{t}}\right)+\alpha_{3}\left[\operatorname{Ln}\left(\mathrm{REER}_{\mathrm{t}}\right)+\operatorname{Ln}\left(P_{t}^{c *}\right)\right]-\operatorname{LnR}_{\mathrm{t}}+\mathrm{v}_{1 \mathrm{t}}$

The expected sign is $\alpha_{1}>0, \alpha_{2}>0$, and $\alpha_{3}>0$.

Inflation Function

$\operatorname{LnP}_{\mathrm{t}}=\delta_{0}-\delta_{1} \operatorname{Ln}\left(\mathrm{M}_{\mathrm{t}}\right)+\delta_{2} \operatorname{Ln}\left(\mathrm{Y}_{\mathrm{t}}\right)+\alpha 3\left[\operatorname{Ln}\left(\operatorname{REER}_{\mathrm{t}}\right)+\operatorname{Ln}\left(P_{t}^{*}\right)\right]+\mathrm{v}_{2 \mathrm{t}}$

The expected sign is $\delta_{1}>0, \delta_{2}>0$, and $\delta_{3}>0$

Real Exchange Rate of Rupiah Function

$\operatorname{Ln}\left(\operatorname{REER}_{\mathrm{t}}\right)=\mu_{0}+\mu_{1} \operatorname{Ln}\left(\mathrm{P}_{\mathrm{t}}\right)-\mu_{2} \operatorname{Ln}\left(P_{t}^{*}\right)-\mu_{3} \operatorname{Ln}\left(P_{t}^{c *}\right)+\mathrm{v}_{3 \mathrm{t}}$

The expected sign is $\mu_{1}<0, \mu_{2}>0$, and $\mu_{3}<0$

Where:

$\mathrm{M}_{\mathrm{t}} \quad$ = amount of circulating money in three-monthly $\mathrm{t}$ period

$\mathrm{M}_{\mathrm{t}-1} \quad=$ amount of circulating money in previous three-monthly $\mathrm{t}$ period

$\mathrm{DEH}_{\mathrm{t}} \quad=$ Deficit of budget in three-monthly $\mathrm{t}$ period

REER $_{t} \quad$ =Real exchange rate of Rupiah in three-monthly t period

$\mathrm{P}^{\mathrm{c}^{*}}{ }_{\mathrm{t}} \quad=$ World CPO price in three-monthly $\mathrm{t}$ period

$\mathrm{P}_{\mathrm{t}} \quad=$ Domestic Inflation in three-monthly $\mathrm{t}$ period

$\mathrm{R}_{\mathrm{t}} \quad=$ Interest rate in three-monthly $\mathrm{t}$ period

$\mathrm{Y}_{\mathrm{t}} \quad=$ Economic Growth in three-monthly $\mathrm{t}$ period

$\mathrm{P}_{\mathrm{t}}^{*} \quad=$ World inflation in three-monthly $\mathrm{t}$ period

$\mathrm{V}_{\mathrm{it}} \quad=$ Error term equation in three-monthly $\mathrm{t}$ period

\section{EMPERICAL RESULTS}

\subsection{The Estimation of Simultanous Equation}

In table 2, the estimation result using Eview 6.0 shows that the variables used are according to the expectation. Statistically, the models used are $t$ test, f test, and $r^{2}$ test. The simultaneous equation system uses normality assumption and auto-correlation assumption.

The result of the estimation below is acquired through Two Stage Least Square (2SLS) model for three-monthly 2008(q1-q4) - 2015(q1-q4) period. Below is the description of the relation between variables acquired from the simultaneous equation above.

TABLE 2. The Result of Estimation of Structural Equation with TSLS

\begin{tabular}{|c|c|c|c|c|}
\hline $\begin{array}{l}\text { Structural } \\
\text { Equation }\end{array}$ & $\begin{array}{l}\text { Endogenous } \\
\text { Variables }\end{array}$ & $\begin{array}{l}\text { Exogenous } \\
\text { Variables }\end{array}$ & Coefficient & Statistical Summary \\
\hline \multirow[t]{2}{*}{ I } & \multirow[t]{2}{*}{$\overline{\mathrm{LnM}_{\mathrm{t}}}$} & $\mathrm{c}$ & $\begin{array}{l}-25.88696^{*} \\
(0.0514)\end{array}$ & \\
\hline & & $\operatorname{LnM}_{t-1}$ & $\begin{array}{l}1.355583^{*} \\
(0.0168)\end{array}$ & \\
\hline
\end{tabular}




\begin{tabular}{|c|c|c|c|c|}
\hline & & $\mathrm{LnDEH}_{\mathrm{t}}$ & $\begin{array}{l}0.694028^{*} \\
(0.0340)\end{array}$ & R-Squared 0.916022 \\
\hline & & $\begin{array}{l}\left(\operatorname{LnREER}_{\mathrm{t}}+\mathrm{Ln}\right. \\
\left.\mathrm{P}^{\mathrm{C}^{*}}{ }_{\mathrm{t}}\right)\end{array}$ & $\begin{array}{l}1.029581^{*} \\
(0.0710)\end{array}$ & $\begin{array}{l}\text { Adjusted R-Squared } \\
0.903102\end{array}$ \\
\hline & & $\mathrm{LnR}_{\mathrm{t}}$ & $\begin{array}{l}-2.287992^{*} \\
(0.0000)\end{array}$ & $\begin{array}{l}\text { Prob (F-Statistics) } \\
0.000000\end{array}$ \\
\hline II & $\mathrm{LnP}_{\mathrm{t}}$ & $\mathrm{c}$ & $\begin{array}{l}-6.760306^{*} \\
(0.0002)\end{array}$ & \\
\hline \multirow{10}{*}{ III } & \multirow{10}{*}{ LnREER $_{t}$} & $\operatorname{LnM}_{t}$ & $\begin{array}{l}-0.070724^{*} \\
(0.3182)\end{array}$ & R-Squared0.482327 \\
\hline & & $\operatorname{LnY}_{t}$ & $\begin{array}{l}0.019695^{*} \\
(0.8904)\end{array}$ & $\begin{array}{l}\text { Adjusted R-Squared } \\
0.424808\end{array}$ \\
\hline & & $\left(\right.$ LnREER $_{t}+$ Ln & $1.067507^{*}$ & Prob (F-Statistics) \\
\hline & & $\left.\mathrm{P}_{t}^{*}\right)$ & $(0.0001)$ & 0.000423 \\
\hline & & $\mathrm{c}$ & $\begin{array}{l}12.56664^{*} \\
(0.0000)\end{array}$ & \\
\hline & & $\mathrm{LnP}_{\mathrm{t}}$ & $0.115784^{*}$ & \\
\hline & & & $(0.0445)$ & R-Squared 0.707368 \\
\hline & & $\operatorname{LnP}_{t}^{*}$ & $\begin{array}{l}-0.006841^{*} \\
(0.9542)\end{array}$ & $\begin{array}{l}\text { Adjusted R-Squared } \\
0.674854\end{array}$ \\
\hline & & $\operatorname{LnP}^{\mathrm{C}^{*}}{ }_{\mathrm{t}}$ & $-0.565455^{*}$ & Prob (F-Statistics) \\
\hline & & & $(0.0004)$ & 0.000000 \\
\hline
\end{tabular}

Source: Eviews 6.0

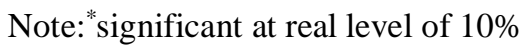

Based on the analysis, regression model is obtained as follows:

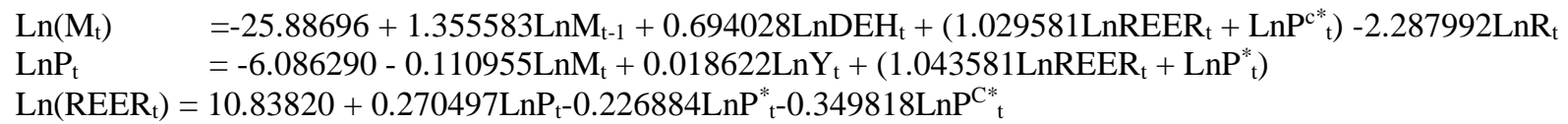

\subsection{The Influence of World CPO Price to the Supply of Money}

The amount of money circulating in the first lag (the previous three-months period) significantly influences the amount of money circulating at the $10 \%$ level, standing at positive value at 1.355583 , meaning that if the circulating money increases $10 \%$, the amount of money circulating at the present time will increase as much as 1.355583 . This supports the result of the previous research by Aprina (2014), where the growth of money in the first lag significantly influence the growth of money at $5 \%$ level positively at 0.875031 . Thus, if the growth of money in the first lag increases by $10 \%$, the growth of money at this rate will increase as much as 8.75031 percent, assuming that other variables are constant. This indicates that the growth of people's need from time to time continously increases. Human beings in general can never be satisfied with their possessions, and therefore, the growth of money circulating in the previous period is assumed to increase the needs of money at the present time. The similar case also happened in Columbia, as Edward (1986) found. He successfully proved the positive influences of the first three lags of circulating money growth to the growth of money circulating at the present time.

The influence of budget deficit is significant against the amount of money circulating at $10 \%$ level at positive value of 0.694028 . This means that if budget deficit increases by $10 \%$, the amount of money circulating will be appreciated at 6.94028 percent, assuming that other variables are constant. This result is not in line with the theory, because if the government suffers deficit in the national budget funds, the government must issue a policy which allows addition of money. This means that there will be an addition in the amount of money circulating. This supports the previous study by Prayitno et al (2002), who suggest that in the long term the variable of government's expenses is significant against the amount of money circulating (M2), because government's expenses are covered in Rupiah; therefore, it directly affects the amount of money circulating in general sense (M2). This result is confirmed by Riwayati and Bellia (2008), who suggest that government's expenses, foreign exchange reserves, and the doubling figure for money give partially significant and significant influence to the amount of money circulating (M2) for 2005-2008 period, which if the government expenses, foreign exchange reserves, and the doubling figure for moneyrise, the amount of money circulating will also increase.

The movement of real exchange rate of Rupiah and world CPO price against the money supply gives significant influence at $10 \%$ level with positive value at 1.029581 , meaning that if the two increase by $10 \%$, the supply of 
money at the present time will increase by 1.029581 percent. Because Rupiah is depreciated against foreign currency, it increases the export demand, while the import value decreases (if the export and import demand are realistic enough); therefore, the supply of money will increase. This is in line with the theory of money quantity which is a theory of direct correlation between changes in the supply of money and changes of price of goods. This supports the finding of Edward (1986) in which the real exchange rate and world CPO price are crucial factors that influnce the domestic price of a commodity; therefore, the sum of two variables can mean the growth of domestic price. Based on the above estimation, it can be concluded that the growth of CPO's domestic price significantly influences the supply of money. The increase of domestic price against CPO will improve the needs of money. Meanwhile, the research result conducted by Iskandar (2015) reveals that the change of world market's price of CPO gives positive influence to the supply of money. This means that the increase of world CPO price increases the supply of money.

Interest rate brings significant influce on the supply of money at $10 \%$ level at negative value of -2.287992 . It means that if the interest rate falls, people will tend to borrow money and so the supply of money isincreasing. When the interest rate increases, people will save more, meaning that the supply of money decreases by -2.287992 . The higher the interest rate, the lower the demand of money. This means that one of the key factors of bank's success in the future is to maintain the interest rate for credit to remain low so that it accelerates the growth in the real sectors especially in credit investment and work capital, which can mean the demand of money increases. It means that when Bank of Indonesia increases their rate, banks need not to increase their credit interest rate. It is advised that banking constantly decrease their credit interest rate so that people can have more money to do transaction as well as to invest. This is in line with the research conducted by Oktavia et al (2013) who suggest that if interest rate is depreciated, the supply of money will experience appreciation. Conversely, the increase of interest rate will decrease the demand of money. The supply of money in Indonesia is determined by the domestic interest rate in reverse flow. This is caused by the monetary policy in overcoming inflation, wherein the inflation is high, one of the monetary policies is to lower the inflation by increasing interest rate. This results in investors coming to Indonesia to invest their capital in Indonesia. The decrease of domestic prices of goodscan be controlled or experience decrease. The decrease in prices will cause the supply of money falls. Conversely, when the interest rate falls, the supply of money will rise.

This result is also supported by research conducted by Maria et al (2017). The influence of interest rate to the supply of money is at -0.021 with significance level at 0.753 . This means that the interest rate gives significantly negative influence to the supply of money. The interest rate increases as the supply of money decreases, because people tend to save their money in the bank to gain higher income through higher interest rate. In contrast, when the interest rate is getting lower, the supply of money is getting higher, because people tend to withdraw their money from the bank for investment and consumption.

\subsection{The Influence of Supply of Money to Inflation}

The supply of money is not significant but the coefficient sign is negative at -0.110955 . This means that when the supply of money is at $10 \%$, inflation will be level down by -0.110955 percent. This is caused by the fact that the supply of money in general sense consists of the circulating money, foreign currency, and quasi-money. It is assumed that the percentages of quasi-money consisting of termed deposit, savings, and foreign currency accounts owned by private domestic holders are big enough. Quasi-money in this case is non-liquid value; therefore, even if the value is high it is not enough to affect the increase of inflation. This is explained by Langi et al (2014), who suggest that the change of percentage in supply of money in short term (DinJUb) shows negative correlation and is not significant against the change of percentage of inflation rate in Indonesia when the other variables do not show changes as much as -3.660953 percent. This is not in line with the theory in which higher supply of money will increase the percentage of inflation in Indonesia. This means that when the change of supply of money increases by 1 percent, the change of percentage of inflation is depreciated at -3.660953 percent. This supports Hartomo (2010) in which normality test (J-B Test) in Ordinary Least Square (OLS) method shows that the supply of money gives negative influence on inflation rate. This way, the inflation rate is going to rocket when the prices of goods increase constantly due to the high supply of money and the rise of exchange rate of Rupiah against American Dollar, which consequently causes crisis.

Economic growth does not show any significant influence to inflation with positive value at 0.018622 . This means that when the economic growth reaches $10 \%$ level, it will be appreciated by inflation by 0.018622 . This is due to the fact that when the economy is growing, investors will come in flocks to invest their capital in the respective country. When investors invest their capital, there will be employment which can increase the income of people. When people's income increases, the need for consumption will also increase. When demand goes up, the prices of goods will consequently go up, causing an inflation. When the inflation rate is high, the wealth will be allocated for physical capitals. Furthermore, some developmental theories suggest that inflation can be used as a mean to mobilize sources as accumulation of capital. This is supported by research conducted by Aprina (2014) who states 
that the economic growth shows positive sign in inflation at $3.92 \%$. When there is an increase in the economy at $10 \%$ level $(3.92 \%)$, the economic growth of a country can cause inflation. This claim is supported by Muqrobi and Pujiati (2011) who suggest that the economic growth and inflation have two positive courses.

The correlation of the movement of real exchange rate of Rupiah and world's inflation against domestic inflation shows significantly positive value at 1.043581 . This means that when there is a movement in the real exchange rate of Rupiah with world inflation rising by $10 \%$, the domestic inflation will be appreciated at 1.043581 . This is caused by the fact that inflation describes the level of increase in the prices of goods in the community. The increase of prices of goods triggers the inflation, which also causes the purchasing power of a certain good to decrease because the same amount of moneyin the previous year cannot be used to purchase the same good in the present year, which then causes Rupiah to be appreciated. This supports the claim by previous research, Aprina (2014), which suggests that the appreciation of exchange rate by world inflation gives significantly positive influence to the inflation. In the model, the two variables possess similar coefficient, which is 1.38 .

This means that the growth of exchange value (appreciation) or world inflation at $10 \%$ will increase the domestic inflation level by 1.38. This result is supported by Saputra and Dharmadiaksa (2013) who show that the exchange rate gives positive and significant influence in inflation in Indonesia. When the exchange rate of Rupiah experiences appreciation, the prices of exported goods will increase, causing the cost of raw materials for import to increase. The rise of prices of import raw materials causes the production result to fall, which in turn causes the scarcity of goods and thus triggers the increase of prices of domestic goods in general, and thus inflation. From demand side, the depreciation of exchange rate causes the prices of foreign goods to become relatively higher compared to domestic products. This causes the increase of demands for domestic goods both from foreign demand and domestic demand against the exported goods. This condition causes the rise of prices of goods which induces inflation to be appreciated.

\subsection{The Effects of Inflation Against the Real Exchange Rate of Rupiah}

The effect of inflation on the real exchange rate gives significantly positive influence by 0.270497 percent. If the inflation experiences an increase, the movement of exchange rate of Rupiah is also increasing. However, this finding goes against the existing theory wherein the increase of inflation causes the exchange rate of Rupiah to decrease. Inflation has significant effect on the exchange rate of Rupiah, meaning that there needs to be an inflation control by the government in order to minimize the level of inflation so that it can decrease the exchange rate value. This, in turn, will give significance for the domestic and international economy players in the international market.

This finding supports the claim of previous research by Istiqomah (2011) in which the regression result shows that the coefficient of the price level gives significantly positive effect. It means that the IHK experiences increase by $1 \%$ or inflation happens at $1 \%$ rate, and therefore, the exchange rate of Rupiah against US dollar is appreciated at 0.366829 percent. This result shows that higher inflation level in Indonesia can cause the exchange rate of Rupiah to be appreciated against US dollar. This is in line with the research conducted by Aprina (2014) which concludes that the relation between the real exchange rate and inflation gives significant influence. Oktavia (2013) suggests that the relation between inflation and the exchange rate is positive. Based on the Purchase Power Parity approach, when inflation occurs, in order to maintain the balance of Law of One Price, the exchange rate needs to be depreciated.

The world inflation against the exchange rate is not negatively significant at -0.226884 to become -2.26884 percent This is caused by the fact that inflation in other countries happen due to the rise of imported goods' prices. This can be caused by high production costs in foreign countries or the increase of import tariff; therefore, the value of currency is depreciated. The currency which experience decrease or imbalance causes the country's economy to be affected as well. This becomes the cause of inflation in a country. When the value of a currency decreases, the prices of goods consequently will increase. This is supported by the research by Madura (2006) who explains that when the inflation in a country increases, the demand of their currency will decrease due to the decrease of export (caused by high prices of goods). This finding is also consistent with the findings of Oriavwote andEshenake (2012) which conclude that world inflation causes the real exchange rate of Rupiah to be depreciated.

The world CPO price against the real exchange rate of Rupiah shows negatively significant value at -0.349818 . This means that the export price of CPO experienced decrease by $10 \%$, meaning that the development of real exchange rate of Rupiah experienced appreciation at -3.49818 percent. The decrease of world CPO price caused the exchange rate to be appreciated. This support the previous research by Aprina (2014) who concludes that the world CPO price gives significantly negative effect against the exchange rate at -0.2 percent. This means that the growth of world CPO price experiences increase by $10 \%$, even though the growth of exchange rate is depreciated by 2 percent. The rise of CPO price will increase the demand of Rupiah from the importer's price, and so the value of Rupiah will be depreciated. This result is also consistent with the research finding by Iskandar (2015) which reports that the increase of CPO price in the international market causes the exchange rate of Rupiah to weaken. The depreciation of 
Rupiah is expected due to the increase in the demand (need) of foreign exchange in the needs of paying CPO import to Indonesia.

\section{CONCLUSION}

According to the testing using 2 SLS model, the direct effect of world CPO price to the mechanism of changes of real exchange rate of Rupiah is negative and significant, but the indirect effect of world CPO price to the mechanism of changes of real exchange rate of Rupiah through the supply of money, interest rate, and inflation is positive and significant. The decrease of world CPO price increases the supply of money; therefore, to decrease the supply of money, the government decreases the interest rate which causes businessmen to increase their loans in order to expand their business which eventually leads to employment opportunities. The increase of work force causes the supply of money to increase which eventually leads to inflation. The government's policy in lowering the inflation is to decrease the prices of goods in foreign market while at the same time increase the domestic value of money which causes the real exchange rate of Rupiah to be depreciated.

Departing from the conclusion above, the government needs to implement an intervention policy because Bank of Indonesia as the central bank in Indonesia still frequently performs intervention in the foreign exchange market. This causes pseudo-stability of exchange rate. The economy policy performed by Bank of Indonesia as a monetary authority in controlling or managing the economy to a better or desired condition is by moderating the supply of money and the interest rate. This monetary policy aims to control the supply of money in order to avoid over supply, which leads to the worsening money value. The government can intervene in shaping the prices in the market. This measure is taken by the government in order to control the price and protect producers and the consumers while at the same time controlling inflation rate which is intended to maintain the price of Indonesian CPO to stay competitive in the international market. This way, CPO as an export commodity can stay unaffected by the change of real exchange rate of Rupiah.

\section{REFERENCES}

Aprina H. 2014. “The Impact of Crude Palm Oil Price on Rupiah's Rate.” Buletin Ekonomi Moneter dan Perbankan 16, no. 4: 315-338 retrieved from: http://www.journal bank indonesia .org/index.php/BEMP/ article/view/15/9 on April 20, 2016

Badan Pusat Statistik (BPS). 2015. "Statistik Kelapa Sawit Indonesia.”Berbagai Edisi Tahun Penerbit. Jakarta.

Chen Y.C. and Rogoff K. 2003. "Commodity Currencies.”Journal of International Economics, Elsevier 60, no. 1: 133-160 retrieved from: http://faculty.washington.edu/yuchin/Papers/JIE2003.pdf on April 20, 2016.

Dornbush, et al. 2008. "Macroeconomics. ”Fourth Edition.Singapura: McGraw-Hill.

Ditria Y, et al. 2008. "Pengaruh Tingkat Suku Bunga, Nilai Tukar Rupiah dan Jumlah Ekspor Terhadap Tingkat Kredit Perbankan.” Journal of Applied Finance and Accounting1, no. 1:166-192 retrieved from:journal.binus.ac.id/index.php/JAFA/article/download/121/117 on November 1, 2017.

Edward S. 1986. "Commodity Export Price and The Real Exchange Rate in Development Country: Coffee In Columbia." Economic Adjustment and Exchange Rates in Developing Countries, 235-266 retrieved from: http://citeseerx.ist.psu.edu/viewdoc/download?doi=10.1.1.459.624\&rep=rep1\&type=pdf on April 20, 2016.

Gujarati D. 2012. “Ekonometrika Dasar.”Edisi Kelima. Erlangga. Jakarta.

Hardy J. 2015. “Analisis Determinan Ekspor CPO Indonesia Ke Uni Eropa.”Jurnal Ilmiah 'Integritas' 1, no. 4: 100110 retrieved from: http://docplayer.info/50441126-Analisis-determinan-ekspor-crude-palm-oil-cpoindonesia-ke-uni-eropa.htmlonApril 20, 2016.

Hartomo H.A. 2010. "Pengaruh Jumlah Uang Beredar dan Kurs Terhadap Tingkat Inflasi Di Indonesia Sebelum dan Setelah Krisis Global 2008." Media Ekonomi18, no. 3:1-22 retrieved from: https://media.neliti.com/media/publications/52743-ID-pengaruh-jumlah-uang-beredar-dan-kurs-te.pdfonApril 20, 2016.

Huda E.N. dan Widodo A. 2017. "Determinan Dan Stabilitas Ekspor Crude Palm Oil Indonesia.”Jurnal Ekonomi dan Bisnis20, no. 1: 45-66 retrieved from:ejournal.uksw.edu/jeb/article/download/518/pdfonApril 20, 2016.

Iskandar A. 2015 ."The Impact of the CPO Price World of Value Commodity Exports of Palm Oil and The Indonesian Economy (The Approach Vector Autoregression Analysis)." Artha Info Journal Accounting High School (state) Vol. BOOTH I/XIII/2015 - ISSN 0852-6737. Istiqomah. "Pengaruh Inflasi dan Investasi Terhadap Nilai Tukar Rupiah.”Signifikan Vol. 2 No. 1 April (2013).Jakarta.retrieved from: http://repository.uinjkt.ac.id/dspace/bitstream/123456789/3862/1/ISTIQOMAH-FEB.pdf on April 20, 2016.

Johan K, et al. 2016. "Analisis Pengaruh Pertumbuhan Ekonomi, Inflasi dan Investasi Terhadap Pengangguran di Indonesia." Jurnal Ilmiah Progresif Manajemen Bisnis (JIPMB) 13, no. 2: 20-32 retrieved from: http://ejurnal.stie-ibek.ac.id/index.php/JIPMB/article/view/177/pdf on April 20, 2016.

Kementrian Perdagangan Republik Indonesia. 2015. Nilai Tukar Mata Uang Asing Terhadap Rupiah Bulanan 20082015. Retrieved from: Http://www.Kemendag.Go.Id/Id/Economic-Profile/Economic-Indicators/Exchange$\underline{\text { Rates }}$

Khalwaty T. 2010. “Inflasi dan Solusinya.” PT Gramedia Pustaka Utama. Jakarta. 
Langi T.M, et al. 2014. "Analisis Pengaruh Suku Bunga Bi, Jumlah Uang Beredar, dan Tingkat Kurs Terhadap Tingkat Inflasi Di Indonesia." Jurnal Berkala Ilmiah Efisiensi. Volume 14 no. 2 - May (2014).

Madura J. 2006. “International Corporate Finance." Keuangan Perusahaan Internasional.Edisi 8.Buku 1. Jakarta: Salemba Empat.

Mankiw N. G. 2007. “Makroekonomi.”Edisi Keenam. Jakarta: Erlangga.

Maria J.A, et al. 2017. "Pengaruh Tingkat Suku Bunga, Inflasi Dan Pertubuhan Gross Domestic Product Terhadap Jumlah Uang Beredar Di Timor-Leste.” E-Jurnal Ekonomi dan Bisnis Universitas Udayana 6.10: 3477-3514.

Muqrobi S. dan Pujiati A. 2011. "Inflasi dan Pertumbuhan Ekonomi:Uji Kausalitas.” Jurnal Dinamika Keuangan dan Perbankan 3, no. 1.

Nilawati. 2000. "Pengaruh Pengeluaran Pemerintah, Cadangan Devisa Dan Angka Pengganda Uang Terhadap Perkembangan Jumlah Uang Beredar Di Indonesia.” Jurnal Bisnis dan Akuntansi. Vol. 2.August. P, 64-72.

Oktavia A.L, et al. 2013. “Analisis Kurs dan Money Supply Di Indonesia.” Jurnal Kajian Ekonomi 1, no. 2: 149-165 retrieved from: http://ejournal.unp.ac.id/index.php/ekonomi/article/view/746/615 on April 20, 2016.

Oriavwote V.E and Samuel, J.E. 2012. "Real Exchange Rate and Inflation: An Empirical Assessment of the Nigerian Experience."Mediterranen Journal of Social Sciences3, no. 3: 145-154 retrieved from:http://citeseerx.ist.psu.edu/viewdoc/download;jsessionid=FA42259D7613B3F552D5380C3EF76C85?d oi=10.1.1.655.7417\&rep=rep1\&type=pdf on April 20, 2016.

Pratiwi T.E. dan H, Purbayu.B.S. 2012. "Analisis Perilaku Kurs Rupiah (IDR) terhadap Dollar Amerika (USD) pada Sistem Kurs Mengambang Bebas di Indonesia Periode 1997.3 - 2011.4 (Aplikasi Pendekatan Keynesian Sticky Price Model)."Diponegoro Journal of Economics 1, no. 1: 1-13 retrieved from: http://ejournal3.undip.ac.id/index.php/jme/article/view/646/646 on April 20, 2016.

Prayitno L, et al. 2002. "Faktor-faktor Yang Berpengaruh Terhadap Jumlah Uang Beredar Di Indonesia Sebelum Dan SesudahKrisis : Sebuah Analisis Ekonometrika." Journal of Management and Entrepreneurship 4, no. 1: 46-55 retrieved from: http://jurnal manajemen.petra.ac.id/index.php/man/article/viewFile/15621/15613 on April 20, 2016.

Prasetiantono, T.A. 2000. “Keluar Dari Krisis :Analsis Ekonomi Indonesia.”PT.Gramedia Pustaka Utama, Jakarta.

Radifan F. 2014. "Economic Development Analysis." Jurusan Ekonomi Pembangunan, Fakultas Ekonomi, Universitas Negeri Semarang, Indonesia3, no. 2: $259-267$ retrieved from:journal.unnes.ac.id/artikel_sju/edaj/3829/3459 on April 20, 2016.

Riwayati H.E. and Bellia N. "Analisis Pengaruh Pengeluaran Pemerintah, Cadangan Devisa, dan Angka Pengganda Uang Terhadap Jumlah Uang Beredar Di Indonesia.Karyallmiah.Fakultas Ekonomi dan Bisnis PERBANAS INSTITUTE.'FakultasEkonomidanBisnisPERBANAS INSTITUTE.2008.Retrieved

from: http://repository.perbanas.id/xmlui/handle/123456789/419 on April 20, 2016.

Saputra I G.A.A. and Dharmadiaksa I.B. 2016. "The Influence of the rate of interest, the exchange rate of the Rupiah, Leverage, and profitability on the Return Shares.” E-Accounting Journal Udayana University Vol.16.2.August (2016).

Sitepu E.S. 2005. "Model Struktural Inflasi dan Pertumbuhan Ekonomi Sumut." Jurnal Bisnis dan Ekonomi 5, no. 12. retrieved from: http://www.oocities.org/eddiestp1175/struktural.htm on April 20, 2016.

Subagyo F.S, et al. .(2005).“Bank dan lembaga keuangan lainnya.” Edisi 2. Yogyakarta: Yayasan Keluarga Pahlawan Negara

Sukirno S. 1981."Ekonomi Pembangunan.” Medan: Penerbit Borta Gorat.

Sukirno S. 1998. "Makroekonomi." Jakarta:Penerbit PT Raja Grafindo Persada.

Sukirno S. 2004. "MakroEkonomi”. Edisi Ketiga. Jakarta: PT. Raja Grafindo Persada.

Turnip L.M.S, et al. (2016). “Analysis Daya Saing CPO Indonesia di Pasar Internasional.”Jurnal Administrasi Bisnis39, no. 1 : $185-194 \quad$ retrieved http://administrasibisnis.studentjournal.ub.ac.id/index.php/jab/article/view/1550/1933 on April 20, 2016.

Unctad. 2015."Free Market Commodity Price Annual. "retrieved from: http://unctadstat.unctad.org/ReportFolders/reportFolders.aspx on April 20, 2016.

Widodo S.T. 1990. "Indikator Ekonomi Dasar Perhitungan Perekonomian Indonesia.” Jakarta: Kanisius. Aprina, H. “Analisis Pengaruh Harga Crude Palm Oil (CPO) Dunia Terhadap Nilai Tukar Riil Rupiah.”Buletin Ekonomi Moneter dan Perbankan. Volume 16, No. April 4,2014.

Wirdayanti H. 2017. “Analisis Faktor-Faktor Yang Mempengaruhi Ekspor Minyak Kelapa Sawit Di Indonesia Tahun 2008-2015.”[Skripsi].UniversitasAndalas. Retrieved from:scholar.unand.ac.id/31396/1/cover\%20DAN\%20ABSTRAK.pdf on April 20, 2016.

Wulansari E, et al. 2016. "Pengaruh Jumlah Produksi, Harga Internasional, Nilai Tukar Dan Tingkat Suku BungaTerhadap Tingkat Daya Saing Ekspor Kelapa Sawit Indonesia (Studi padaTahun 2009-2013).”.Jurnal Administrasi Bisnis.Vol 39 No.2 (2016). 